\title{
Peran Budaya Kerja dan Kompensasi Pada Kinerja Aparatur Sipil Negara (ASN) di Kantor Kementerian Agama Kota Baubau
}

\author{
Samsul Bahari ${ }^{*}$ \\ ${ }^{1}$ Universitas Muhammadiyah Buton, Indonesia \\ *Korespondensi: sulbahari7@gmail.com
}

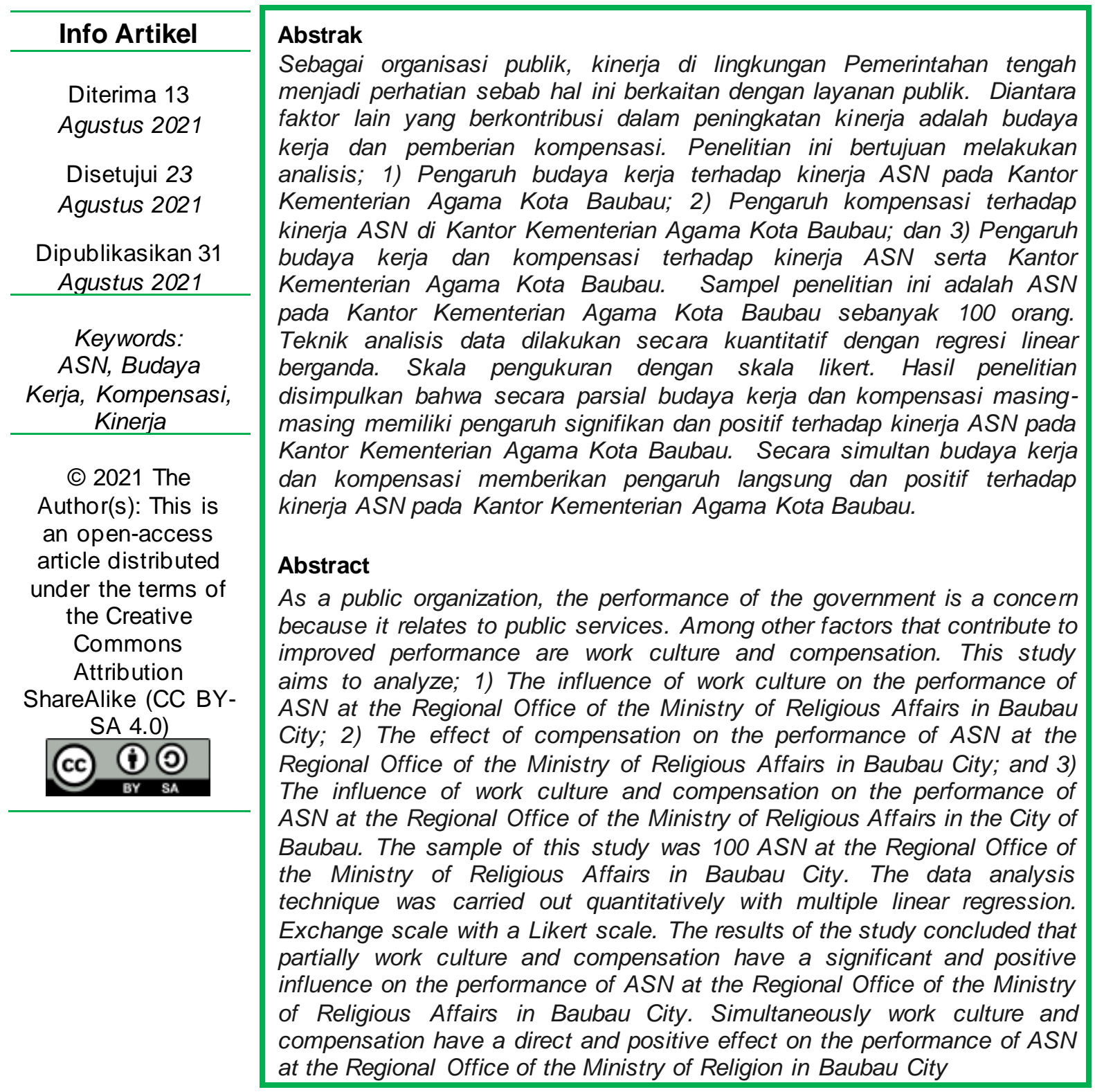




\section{Pendahuluan}

Terdapat beberapa faktor yang memberikan pengaruh pada kinerja karyawan, yakni pemberian kompensasi, kondisi lingkungan kerja, dan budaya yang berlaku pada masing-masing organisasi (Golung, 2013). Dalam praktiknya, tiap pemimpin dan aparatur negara tidak hanya kesulitan berbenah dan berubah menjadi lebih baik melainkan juga seringkali tidak menghiraukan setiap nilai moral serta budaya kerjanya sebagai aparatur negara.

Budaya kerja yakni sebuah pemahaman, terhadap sikap juga perilaku yang wajib dimiliki setiap orang ketika bekerja dalam sebuah organisasi ataupun institusi. Nilai yang dipegang setiap orang yang teraplikasikan dalam budaya kerjanya sangat menentukan kualitas pekerjaan seseorang ataupun sekelompok orang. Jika seluruh pegawai memiliki etos kerja dengan kualitas tinggi maka kualitas pelayanan terhadap publik yang di fasilitasi oleh pemerintah baik di pusat maupun pemerintah daerah juga akan berkualitas tinggi (Frinaldi, 2014)

Adanya berbagai budaya kerja yang bersifat negatif dan masih tertanam kuat dalam diri tiap pegawai dalam pelaksanaan tugas dan kewajibannya menjadi penghambat yang cukup mempengaruhi kinerja suatu organisasi (Zulkifli \& Dkk, 2014). Menurut Frinaldi (Frinaldi, 2014) menyatakan bahwa ketika sebuah lembaga atau instansi menerapkan dengan kuat budaya kerja yang positif dalam aktivitas bekerjanya, dapat mewujudkan sinergitas antara staf bersama pimpinan sehingga pimpinan bisa fokus pada hal yang lebih besar dari pada sekadar menyelesaikan konflik internal dikarenakan perbedaan budaya yang dianut para pegawai dalam bekerja. Dengan demikian suatu instansi dapat menyediakan layanan publik yang lebih berkualitas dan prima. Karena itu menurut (Frinaldi, 2014) yang dimaksud layanan publik dengan integritas yakni suatu layanan yang dilaksanakan dengan senang hati berdasar pada karakter moral dan etika yang benar. Hal tersebut dimaksudkan sehingga layanan yang disediakan kepada masyarakat dapat menghasilkan banyak kebaikan kepada setiap pengguna jasa layanan publik. Jika pelayanan demikian diaplikasikan setiap instansi pemerintah pusat maupun pemerintah daerah maka kepercayaan masyarakat terhadap pemerintah dapat semakin terbangun.

Lemah dan tidak meratanya pengaplikasian budaya kerja yang berkualitas memunculkan stigma masyarakat bahwa para aparatur sipil Negara termasuk ASN tidak begitu paham terkait penerapan budaya kerja positif. Hal tersebut dapat dinilai dari munculnya pandangan mengenai para PNS yang menjadikan pekerjaan masih sebatas rutinitas semata. Bahkan pada sebagian PNS, bekerja mungkin dipandang sebagai beban serta bentuk paksaan untuk para pemalas. Diperlukan adanya alat ukur yang tepat dalam membentuk kategori budaya kerja yang berkualitas sehingga para pimpinan di berbagai instansi pemerintah dapat memberikan beban tugas kepada para pegawainya sesuai dengan kapasitas individu yang diberikan tugas. Penunjukan atau pemberian beban tugas dapat dilakukan secara profesional, bukan agar posisi pimpinan menjadi aman dan terkendali.

Tidak adanya alat ukur yang tepat dalam mengukur kualitas budaya kerja pegawai kemungkinan juga disebabkan oleh ketidakberdayaan pihak pemerintah mengubah struktur, norma, maupun nilai pegawai di instansinya. Hal tersebut menjadi sebab kegagalan dalam usaha mewujudkan aspirasi serta kebutuhan 
masyarakat dan membuat munculnya anggapan dari kalangan masyarakat terkait kualitas layanan dan kinerja birokrasi masih terlalu jauh dari apa yang dibu tu hkan dalam penyediaan layanan publik. Budaya pelayanan publik dengan orientasi kebutuhan pelanggan belum terbangun (service delivery culture). Namun yang ada justru sebaliknya yakni para birokrat dan politisi yang terobsesi mengalih fungsikan birokrasi menjadi kesempatan untuk memuaskan hasrat juga kekuasaan. (power culture). Dalam penelitian Lidya dan Hati (Lidya \& Hati, 2015) menemukan bahwa belum ditemukan formula yang tepat untuk memberikan solusi terhadap pemecahan sebab akibat buruknya kualitas pelayanan publik yang berlangsung turun temurun. Seiring dengan hal tersebut, tuntutan masyarakat terhadap keefektifan kerja pelayanan aparatur Negara terus meningkat.

Image yang melekat mengenai rendahnya kinerja sektor publik telah lama menyebar dan menjadi tidak asing lagi di kalangan masyarakat. Selain kinerja yang rendah, proses birokrasi yang sangat dikenal sulit, bertele-tele, dan dipen u hi intrik praktik suap sehingga menjadikan citra para aparatur yang bergerak di sektor public semakin tercoreng. Dari berbagai permasalahan tersebut, kedepannya perlu dilakukan perubahan budaya organisasi dari yang tidak kondusif kepada budaya organisasi dengan kinerja tinggi serta memiliki ukuran yang jelas dalam menyediakan layanan publik kepada masyarakat. Adapun terdapat beberapa faktor yang menyebabkan lemahnya budaya organisasi di sektor publik yakni: (a) aparat pemerintah lebih dominan berorientasi pada peraturan, bukan pada visi misi organisasinya; (b) Visi dan misi organisasi yang belum begitu jelas; (c) Sistem pemberian kompensasi yang masih kurang layak dan tidak adil; (d) pelayanan masih dominan mengutamakan atasan atau orang yang memiliki pengaruh daripada masyarakat secara umum; (e) Promosi yang masih saja berdasar pada senioritas bukan pada kompetensi individu; (f) maraknya budaya korupsi, kolusi dan nepotisme di lingkungan pekerjaan dari yang terkecil hingga kelas kakap (Frinaldi, 2014).

Berbagai usaha yang ditujukan untuk mengubah budaya organisasi di instansi pemerintah pada hakikatnya telah diupayakan, salah satunya dengan adanya penerapan program budaya kerja aparatur yang dimaksudkan guna mendorong peningkatan produktivitas kerjanya, namun belum menunjukkan hasil yang optimal. Oleh sebab itu upaya mengembangkan perusahaan berkinerja tinggi dalam aspek budaya juga membutuhkan keterlibatan yang kuat dan persetujuan bersama sebagai prasyarat utama untuk menciptakan perusahaan berkinerja tinggi.

Kinerja seseorang terkadang meningkat dan terkadang menurun. Pada prinsipnya yang dimaksud dengan kinerja adalah hasil kerja karyawan dalam waktu dan parameter yang telah ditentukan dan disepakati bersama (Soeprihanto, 2000). Dengan mengukur prestasi kerja yang dikaitkan dengan kinerja yang lebih tinggi. Hal ini dapat memberi motivasi kepada pegawai agar bisa lebih produktif.

Kompensasi yaitu pemberian sejumlah uang sebagai penghargaan terhadap jasa dari prestasi kerja pegawai termasuk didalamnya segala jenis bayaran serta pemberian tunjangan kepada para karyawan. Kompensasi menjadi salah satu upaya guna mendorong peningkatan motivasi serta kinerja para karyawan, selain itu juga menjadi faktor utama sebuah perusahaan merekrut sumber daya manusia yang memiliki kualitas. Nilai kompensasi yang diberikan pada umumnya bersifat transparansi atau telah ditentukan dan disepakati terlebih dahulu. Karyawan telah 
mengetahui dengan pasti besaran kompensasi yang akan diterima (Khusna, 2015).

Secara umum, kategori kompensasi terbagi menjadi dua komponen yakni (1) finansial langsung berupa bayaran yang didapatkan oleh seseorang. (2) non finansial berupa kepuasan karyawan terhadap hasil kerja atau kepuasan psikologis yang diperoleh dari lingkungan kerjanya.

Besarnya kompensasi yang didapatkan menggambarkan status dan tingkat jabatan dari seorang karyawan, jika balas jasa yang didapatkan pegawai terus meningkat mengalamatkan bahwa jabatan pegawai tersebut semakin naik dan statusnya di perusahaan semakin baik. Maka dapat disimpulkan, kepuasan kerja yang dimilikinya juga semakin baik. Dari hal inilah peran penting pemberian kompensasi untuk pegawai sebagai seseorang yang menjual tenaganya baik secara fisik maupun pikiran (Hasibuan, 2008). Kompensasi yaitu segala jenis pendapatan yang berbentuk uang, baik itu barang yang diterima secara langsung ataupun tidak langsung dan dibayarkan kepada karyawan sebagai imbalan atas sumbangsih jasa yang telah mereka berikan (Hasibuan, 2008). Oleh karena itu setiap organisasi perlu menaruh perhatian lebih mengenai pemberian kompen sasi yang tepat, sebab pemberian kompensasi sangat menunjang kualitas kinerja tiap pegawai. Ketika pegawai merasa bahwa kompensasi yang diterima dari suatu instansi tidak sebanding dengan sumbangsih jasa ataupun pengorbanan yang mereka lakukan maka akan memberi dampak buruk pada kelangsungan organisasi tersebut.

Jika setiap organisasi dapat memberikan kompensasi yang sesuai maka kinerja dari setiap pegawai juga akan semakin meningkat, sehingga sangat jelas bahwa pemberian upah dan bonus yang dipikirkan dengan matang dan konstan berdampak signifikan terhadap kinerja pegawai dan visi organisasi dapat terwujud sebagaimana yang telah direncanakan. Hal tersebut berkorelasi dengan hasil penelitian Golung (Golung, 2013) yang menyatakan bahwa kompensasi juga dapat dimaknai penghargaan guna memberikan motivasi kepada pegawai agar memiliki kinerja yang baik dan terus mengalami peningkatan. Hasil penelitian ini menunjukkan bahwa gaji sangat mempengaruhi keberhasilan pekerja Hotel Sedona Manado. Sejalan dengan itu, penelitian Suwandi (Suwandi, 2021) juga menyatakan dimana kompensasi memberikan pengaruh secara signifikan terhadap kinerja pegawai. Sedangkan penelitian Ahmad (Shalahuddin, 2014) justru sebaliknya dimana menyatakan bahwa kompensasi mempunyai pengaruh langsung yang tidak signifikan terhadap kinerja pegawai. Alasannya setiap pegawai harus merasakan keadilan yang sama terhadap kompensasi yang diberikan perusahaan begitu juga dengan besaran kompensasi yang didapatkan harus sesuai dengan apa yang para pegawai harapkan. Oleh karena itu dapat dibuat kesimpulan bahwa para pegawai belum merasakan pemerataan terkait besaran kompensasi yang didapatkan. Selain itu kompensasi tersebut juga belum sesuai dari apa yang mereka harapkan. Dari hasil penelitian tersebut, ekspektasi gaji dan kesuksesan karyawan berbeda.

Kantor Wilayah Kementerian Agama Kota Baubau sebagai organisasi publik, maka pegawai selalu dituntut mampu untuk memenuhi kebutuhan masyarakat Sulawesi Tenggara yang heterogen. Terdapat kinerja pegawai yang masih belum maksimal sebelum diterbitkannya Perpres No.108 Tahun 2014 yang membahas mengenai Tunjangan Kinerja Pegawai di Lingkungan Kementerian Agama. Dalam 
Perpres tersebut dicantumkan bahwa pemberian tunjangan pegawai diberikan dalam rangka pengenalan reformasi birokrasi di lingkungan Kementerian Agama dengan tujuan untuk meningkatkan kinerja pegawai di lingkungan Kementerian Agama.

Tujuan penelitian ini ialah menganalisis: (1) Pengaruh budaya kerja terhadap kinerja ASN pada Kantor Kementerian Agama Kota Baubau; (2) Melakukan analisis pengaruh kompensasi terhadap kinerja ASN pada Kantor Kementerian Agama Kota Baubau; dan (3) Pengaruh Budaya Kerja dan Kompensasi pada kinerja ASN pada Kantor Kementerian Agama Kota Baubau.

\section{Metode Penelitian}

Melalui analisis kuantitatif regresi berganda, penelitian ini bertujuan untuk mengetahui apakah budaya kerja dan kompensasi berpengaruh terhadap kinerja ASN.

Populasi dalam penelitian ialah seluruh pegawai (ASN) di Kantor Kementerian Agama Kota Baubau berjumlah 170 Orang. Teknik pengambilan sample dalam penelitian ini menggunakan random sampling sebanyak 100 responden.

Fokus penelitian ini adalah pada dua variabel yaitu variabel bebas (independent variable) dan variabel terikat (dependent variable). Variabel bebas (independent variable) adalah budaya kerja (X1) dan kompensasi(X2) sedangkan variabel terikat adalah kinerja $(\mathrm{Y})$. Penjelasan dari variabel-variabel tersebut diuraikan sebagai berikut:

a. Budaya kerja; disiplin, keterbukaan, saling menghargai, dan kerjasama.

b. Kompensasi; kompensasi finansial langsung (Bangun, 2012) kompensasi finansial tidak langsung (Rivai \& Sagala, 2009)] dan kompensasi non finansial (Bangun, 2012)

c. Kinerja: tingkat kualitas pekerjaan, jumlah pekerjaan, dan ketepatan waktu.

Analisis kuantitatif dilakukan untuk menghubungkan berbagai variabel dan standar yang ditentukan serta regresi linear berganda dengan SPSS for Windows Release 19,00.

Metode penelitian meliputi analisa permasalahan dan rancangan metode yang digunakan untuk menyelesaikan masalah. Analisa permasalahan mendeskripsikan permasalahan yang ada dan diselesaikan dalam penelitian ini. Rancangan menggambarkan cara penyelesaian masalah.

\section{Hasil}

\subsection{Uji Validitas}

Setiap variabel yang digunakan dalam analisis ini diuji dalam uji validitas, dimana semua variabel pengujian berisi 24 pernyataan yang wajib diisi setiap responden. Parameter berikut digunakan dalam analisis ini yaitu: tingkat kepercayaan $=95 \%(\alpha=5 \%)$, derajat kebebasan $(d f)=n-2=24-2=22$, didapat $r$ tabel $=0,30$. Jika $r$ hitung lebih besar dari $r$ tabel dan nilai $r$ positif, maka butir pernyataan dikatakan valid (Ghozali, 2005). Hasil analisis uji validitas variabel budaya kerja (X1) dan kompensasi (X2) memperlihatkan bahwa nilai r-hitung lebih 
besar dari r-tabel dan menunjukkan nilai $r$ positif, artinya bahwa nilai tersebut dinyatakan valid. Hasil analisis tersebut ditunjukkan pada Tabel 1.

Tabel 1. Hasil Uji Validitas Budaya Kerja dan Kompensasi

\begin{tabular}{|c|c|c|c|c|c|c|}
\hline $\begin{array}{c}\text { Variabel } \\
\text { Penelitian }\end{array}$ & $\begin{array}{l}\text { Indikator } \\
\text { Variabel }\end{array}$ & $\begin{array}{l}\text { Item } \\
\text { (Butir) }\end{array}$ & $\begin{array}{l}\text { Koefisien } \\
\text { Korelasi }(r)\end{array}$ & r tabel & Sig. & Hasil \\
\hline \multirow{10}{*}{$\begin{array}{c}\text { Budaya } \\
\text { Kerja (KE) }\end{array}$} & \multirow{3}{*}{ Disiplin } & BK1.1 & $0,929^{\star *}$ & 0,300 & $\begin{array}{c}0,00 \\
0\end{array}$ & Valid \\
\hline & & BK1.2 & $0,735^{* *}$ & 0,300 & $\begin{array}{c}0,00 \\
0\end{array}$ & Valid \\
\hline & & BK1.3 & $0,835^{\star *}$ & 0,300 & $\begin{array}{c}0,00 \\
0\end{array}$ & Valid \\
\hline & \multirow{2}{*}{$\begin{array}{l}\text { Keterbuk } \\
\text { aan }\end{array}$} & BK2.1 & $0,741^{* *}$ & 0,300 & $\begin{array}{c}0,00 \\
0\end{array}$ & Valid \\
\hline & & BK2.2 & $0,683^{* *}$ & 0,300 & $\begin{array}{c}0,00 \\
0\end{array}$ & Valid \\
\hline & \multirow{3}{*}{$\begin{array}{l}\text { Saling } \\
\text { Menghar } \\
\text { gai }\end{array}$} & BK3.1 & $0,489^{* *}$ & 0,300 & $\begin{array}{c}0,00 \\
6 \\
\end{array}$ & Valid \\
\hline & & BK3.2 & $0,951^{* *}$ & 0,300 & $\begin{array}{c}0,00 \\
0\end{array}$ & Valid \\
\hline & & BK3.3 & $0,593^{* *}$ & 0,300 & $\begin{array}{c}0,00 \\
1\end{array}$ & Valid \\
\hline & \multirow{2}{*}{$\begin{array}{c}\text { Kerjasam } \\
\text { a }\end{array}$} & BK4.1 & $0,690^{\star *}$ & 0,300 & $\begin{array}{c}0,00 \\
0\end{array}$ & Valid \\
\hline & & BK4.2 & $0,856^{\star *}$ & 0,300 & $\begin{array}{c}0,00 \\
0\end{array}$ & Valid \\
\hline \multirow{5}{*}{$\begin{array}{c}\text { Kompensa } \\
\text { si } \\
(\mathrm{K})\end{array}$} & \multirow{2}{*}{$\begin{array}{l}\text { Kompens } \\
\text { asi } \\
\text { Finansial } \\
\text { Langsung }\end{array}$} & $\mathrm{K} 1.1$ & $0,834^{* *}$ & 0,300 & $\begin{array}{c}0,00 \\
0\end{array}$ & Valid \\
\hline & & K1.2 & $0,742^{\star \star}$ & 0,300 & $\begin{array}{c}0,00 \\
0\end{array}$ & Valid \\
\hline & $\begin{array}{l}\text { Kompens } \\
\text { asi } \\
\text { Finansial } \\
\text { Tidak } \\
\text { Langsung }\end{array}$ & K2.1 & $0,915^{\star \star}$ & 0,300 & $\begin{array}{c}0,00 \\
0\end{array}$ & Valid \\
\hline & \multirow{2}{*}{$\begin{array}{l}\text { Kompens } \\
\text { asi Non } \\
\text { Finansial }\end{array}$} & K3.1 & $0,865^{* *}$ & 0,300 & $\begin{array}{c}0,00 \\
0\end{array}$ & Valid \\
\hline & & K3.2 & $0,756^{\star *}$ & 0,300 & $\begin{array}{c}0,00 \\
0\end{array}$ & Valid \\
\hline
\end{tabular}

Hasil analisis uji validitas variabel kinerja pegawai $(Y)$ memperlihatkan bahwa nilai r-hitung lebih besar dari r-tabel dan menunjukkan nilai positif. Hasil analisis tersebut ditunjukkan pada Tabel 2. 
Tabel 2. Hasil Uji Validitas Variabel Kinerja Pegawai

\begin{tabular}{|c|c|c|c|c|c|c|}
\hline $\begin{array}{c}\text { Variabel } \\
\text { Penelitian }\end{array}$ & $\begin{array}{l}\text { Indikator } \\
\text { Variabel }\end{array}$ & $\begin{array}{c}\text { Item } \\
\text { (Butir) }\end{array}$ & $\begin{array}{l}\text { Koefisien } \\
\text { Korelasi }(r)\end{array}$ & $\begin{array}{c}r \\
\text { tabel }\end{array}$ & Sig. & Hasi \\
\hline \multirow{9}{*}{$\begin{array}{c}\text { Kinerja } \\
\text { Pegawai } \\
(\mathrm{KP})\end{array}$} & \multirow{3}{*}{ Kuantitas } & KP1.1 & $0,720^{* *}$ & 0,300 & $\begin{array}{l}0,00 \\
0\end{array}$ & Valid \\
\hline & & KP1.2 & $0,639^{\star *}$ & 0,300 & $\begin{array}{l}0,00 \\
0\end{array}$ & Valid \\
\hline & & KP1.3 & $0,534^{\star *}$ & 0,300 & $\begin{array}{l}0,00 \\
2\end{array}$ & Valid \\
\hline & \multirow{3}{*}{ Kualitas } & KP2.1 & $0,750^{* *}$ & 0,300 & $\begin{array}{l}0,00 \\
0\end{array}$ & Valid \\
\hline & & KP2.2 & $0,750^{* *}$ & 0,300 & $\begin{array}{l}0,00 \\
0\end{array}$ & Valid \\
\hline & & KP2.3 & $0,928^{* *}$ & 0,300 & $\begin{array}{l}0,00 \\
0\end{array}$ & Valid \\
\hline & \multirow{3}{*}{$\begin{array}{l}\text { Ketepata } \\
\text { n Waktu }\end{array}$} & KP3.1 & $0,853^{* *}$ & 0,300 & $\begin{array}{l}0,00 \\
0\end{array}$ & Valid \\
\hline & & KP3.2 & $0,711^{* *}$ & 0,300 & $\begin{array}{l}0,00 \\
0\end{array}$ & Valid \\
\hline & & KP3.3 & $0,681^{\star *}$ & 0,300 & $\begin{array}{l}0,00 \\
0\end{array}$ & Valid \\
\hline
\end{tabular}

Berdasarkan Tabel 2 dapat diketahui dimana nilai dari $r$ hitung di seluruh indikator yang diuji memiliki nilai positif dan lebih besar dari pada nilai $r$ tabel. Dengan demikian, semua butir indikator yang digunakan dalam analisis pen elitian ini lolos dalam uji validitas dan dinyatakan valid.

\subsection{Uji Reliabilitas}

Uji reliabilitas digunakan untuk mengukur konsistensi konstruk atau variabel penelitian. Untuk mengukur uji reliabilitas dilakukan dengan menggunakan uji statistik Cronbach Alpha ( $\alpha$ ). Suatu konstruk atau variabel dinyatakan reliabel ketika nilai koefisien Alpha lebih besar daripada 0,60 (Ghozali, 2005). Hasil uji reliabilitas dalam penelitian ini tertuang pada Tabel 3.

Tabel 3. Hasil Uji Reliabilitas Variabel Penelitian

\begin{tabular}{cccc} 
Kode Variabel & $\begin{array}{c}\text { Cronbach's } \\
\text { Alpha }\end{array}$ & $\begin{array}{c}\text { Nilai } \\
\text { Kritik }\end{array}$ & Ket. \\
\hline $\begin{array}{c}\text { Budaya Kerja } \\
(\mathrm{X} 1)\end{array}$ & 0,941 & $\begin{array}{c}> \\
0,60\end{array}$ & $\begin{array}{c}\text { Relia } \\
\text { bel }\end{array}$ \\
\hline $\begin{array}{c}\text { Kompensasi } \\
(\text { X2) }\end{array}$ & 0,811 & $>0,60$ & $\begin{array}{c}\text { Relia } \\
\text { bel }\end{array}$ \\
\hline $\begin{array}{c}\text { Kinerja Pegawai } \\
(Y)\end{array}$ & 0,775 & $>0,60$ & $\begin{array}{c}\text { Relia } \\
\text { bel }\end{array}$ \\
\hline
\end{tabular}


Variabel yang dipelajari pada Tabel 3 memiliki koefisien yang bervariasi untuk ukuran reliabilitas. Setiap item variabel independen (variabel X) memiliki koefisien Alpha (koefisien korelasi) lebih besar dari atau sama dengan 0,60 dengan setiap item variabel dependen (variabel Y). Maka dapat ditarik kesimpulan bahwa alat ukur yang digunakan dalam penelitian ini adalah reliabel.

\subsection{Uji Normalitas}

Uji normalitas data memiliki tujuan yaitu meyakinkan bahwa data yang ada benar-benar berasal dari populasi yang berdistribusi normal sehingga uji hipotesis dapat dilakukan. Uji normalitas data menggunakan teknik Kolmogorov Smirnov dengan bantuan program SPSS 23.0 for Windows. Hipotesis yang diuji ialah:

H0: Data sampel berasal dari populasi yang berdistribusi normal

H1: Data sampel tidak berasal dari populasi yang berdistribusi normal

Maka hipotesis tersebut dapat diadopsi dan alternatif tersebut tidak dapat ditolak jika nilai a lebih besar dari 0,05. Penerimaan atau penolakan hipotesis nol dinilai dari mengamati bilangan statistik (statistic) dan signifikansi (sig.) pada kolom Kolmogorov Smirnov. Jika tingkat signifikansi 0,05, hipotesis nol akan diterima. Artinya data sampel berasal dari populasi yang berdistribusi normal. Sebaliknya, jika angka signifikansi < 0,05 (sig. < 0,05) maka bilangan statistik yang didapatkan tidak signifikan sehingga hipotesis nol ditolak. Artinya data sampel tidak berasal dari populasi yang berdistribusi normal. Ringkasan hasil uji normalitas terangkum dalam Tabel 4.

Tabel 4. Ringkasan Hasil Uji Normalitas

\begin{tabular}{|c|c|c|c|c|}
\hline \multirow[b]{2}{*}{ Variabel } & \multicolumn{3}{|c|}{ Kolmogorov-Smirnova } & \multirow[b]{2}{*}{ Kesimpulan } \\
\hline & Statistic & Df & Sig & \\
\hline Budaya Kerja (X1) & 1,009 & 98 & $\begin{array}{c}, 26 \\
0 \\
\end{array}$ & Normal \\
\hline Kompensasi (X2) & 1,797 & 98 & $\begin{array}{c}, 30 \\
3 \\
\end{array}$ & Normal \\
\hline $\begin{array}{l}\text { Kinerja Pegawai } \\
(Y)\end{array}$ & 1,100 & 98 & $\begin{array}{c}17 \\
7\end{array}$ & Normal \\
\hline
\end{tabular}

Berdasarkan Tabel 4 bahwa hasil pengujian semua variabel berdistribusi normal dimana semua taraf signifikansi lebih besar dari pada 0,05. Semua bilangan signifikansi yang diperoleh bernilai lebih besar dari 0,05 (sig. >0,05). Artinya bilangan statistik yang diperoleh tidak signifikan sehingga hipotesis nol diterima. Jadi data analisis Pengaruh Budaya Kerja dan Kompensasi terhadap Kinerja ASN pada Kantor Kementerian Agama Kota Baubau berasal dari populasi yang berdistribusi normal. 


\subsection{Pengujian Regresi Linear Berganda}

Berdasar pada hasil perhitungan menggunakan bantuan komputer dari program SPSS for Windows Release 19,00 diperoleh hasil seperti yang tertuang pada Tabel 5.

Tabel 5. Hasil Komputasi Analisis Regresi Berganda

\begin{tabular}{|c|c|c|c|}
\hline $\begin{array}{l}\text { Pengaruh antar } \\
\text { variabel }\end{array}$ & $\begin{array}{c}\text { Koefisi } \\
\text { en } \\
\text { Korelas } \\
i\end{array}$ & t-value & Sig. $t$ \\
\hline $\begin{array}{l}\text { Budaya } \\
\text { Kerja } \square \text { Kinerja } \\
\text { pegawai }\end{array}$ & 0,136 & 2,337 & $\begin{array}{c}0,02 \\
2\end{array}$ \\
\hline $\begin{array}{l}\text { Kompensasi } \\
\square \text { Kinerja pegawai }\end{array}$ & 1,314 & $\begin{array}{c}13,25 \\
6\end{array}$ & $\begin{array}{c}0,00 \\
0\end{array}$ \\
\hline 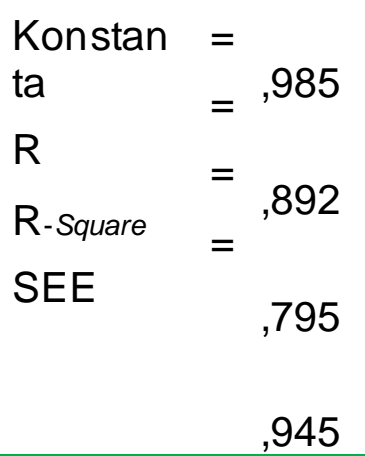 & $\begin{array}{l}\text { F-value } \\
\text { Sig. } F \\
n\end{array}$ & $\begin{array}{l}=118,41 \\
=0.000 \\
=100\end{array}$ & \\
\hline
\end{tabular}

Berdasarkan hasil analisis regresi linear berganda pada Tabel 5. diperoleh persamaan analisis regresi linear:

$$
Y=, 985+0,136 \times 1+1,314 \times 2
$$

Persamaan regresi tersebut mempunyai arti sebagai berikut:

a. Konstanta: $=, 985$

Jika variabel budaya kerja dan kompensasi $=0$, maka Kinerja ASN pada Kantor Kementerian Agama Kota Baubau=,985

b. Koefisien Budaya Kerja (X1): 0,136

Jika Budaya Kerja mengalami kenaikan sebesar 1 point dengan kompensasi dianggap tetap, maka akan menjadi sebab dari kenaikan kinerja ASN pada Kantor Kementerian Agama Kota Baubau akan menjadi sebesar =.0,136.

c. Koefisien Kompensasi (X2):1,314

Jika kompensasi mengalami kenaikan sebesar 1 point dengan budaya kerja dianggap tetap, maka akan menjadi sebab dari kenaikan kinerja ASN pada Kantor Kementerian Agama Kota Baubau akan menjadi sebesar =.1,314. 


\subsection{Pengujian Hipotesis Penelitian}

Rangkuman hasil uji hipotesis variabel data penelitian disajikan Tabel 6.

Tabel 6. Rangkuman Hipotesis Variabel Data Penelitian

\begin{tabular}{|c|c|c|c|c|}
\hline No & Variabel & t hitung & Sig. & Interpretasi \\
\hline \multirow[t]{4}{*}{1.} & $\begin{array}{l}\text { Pengaruh } \\
\text { Parsial }\end{array}$ & & & \\
\hline & $\mathrm{X} 1 \rightarrow \mathrm{Y}$ & 2,337 & $\begin{array}{c}0,02 \\
2\end{array}$ & H1 terbukti \\
\hline & $\mathrm{X} 2, \overrightarrow{\mathrm{Y}}$ & 13,256 & $\begin{array}{c}0,00 \\
0 \\
\end{array}$ & H2 terbukti \\
\hline & & F hitung & Sig. & \\
\hline \multirow[t]{2}{*}{2.} & $\begin{array}{l}\text { Pengaruh } \\
\text { Simultan }\end{array}$ & & & \\
\hline & $\begin{array}{l}X 1, X 2 \vec{Y} \\
Y\end{array}$ & 188,410 & $\begin{array}{c}0,00 \\
0\end{array}$ & H3 terbukti \\
\hline
\end{tabular}

Berdasarkan hasil analisis regresi linear yang ditunjukkan pada Tabel 6 diperoleh pengujian hipotesis secara parsial dan simultan yang bertujuan untuk menjawab hipotesis yang diajukan. Hasil pengujian hipotesis dapat dijelaskan sebagai berikut:

\subsection{Uji Hipotesis Pertama (H1)}

Secara parsial (uji t) dalam penelitian ini bertujuan untuk menguji pengaruh budaya kerja terhadap kinerja ASN pada Kantor Kementerian Agama Kota Baubau adalah:

\section{H1. Ada pengaruh budaya kerja secara signifikan terhadap kinerja PNS}

Berdasarkan hasil penelitian dan perhitungan yang dilakukan dengan menggunakan komputer program SPSS 19 for Windows seperti yang terangkum dalam Tabel 7 dan Tabel 8 menunjukkan secara parsial dengan uji t diperoleh $\mathrm{t}$ hitung $=2,337>\mathrm{t}$ tabel 1,983971 dengan signifikansi 0,022, karena signifikansi yang diperoleh kurang dari 0,05 , menunjukkan bahwa nilai t yang diperoleh tersebut signifikan. Sehingga hipotesis pertama $(\mathrm{H} 1)$ yang diuji dalam penelitian ini, yaitu "Ada pengaruh budaya kerja secara signifikan terhadap kinerja ASN diterima". Hasil pengujian membuktikan bahwa budaya kerja memberi pengaruh yang positif juga signifikan terhadap kinerja PNS. Artinya semakin tinggi budaya kerja ASN maka kinerja ASN pada Kantor Kementerian Agama Kota Baubau akan semakin meningkat. Kesimpulannya hipotesis pertama yang diajukan dalam penelitian ini dapat diterima atau didukung oleh fakta empiris hasil penelitian.

\subsection{Uji Hipotesis Kedua (H2)}

Berdasarkan hasil penelitian dan perhitungan yang dilakukan dengan menggunakan komputer program SPSS for Windows Release 19,00 seperti yang terangkum dalam Tabel 7 dan Tabel 8 menunjukan bahwa Uji keberartian koefisien korelasi dengan uji $\mathrm{t}$ diperoleh $\mathrm{t}$ hitung $=13,256>\mathrm{t}$ tabel 1,983971 dengan signifikansi 0,000 , karena signifikansi yang diperoleh kurang dari 0,05 , 
menunjukkan bahwa nilai t yang diperoleh tersebut signifikan. Sehingga hipotesis kedua (H2) yang diuji dalam penelitian ini, yaitu:

\section{H2 : Ada pengaruh kompensasi secara signifikan terhadap kinerja PNS}

Hasil pengujian membuktikan bahwa kompensasi memberikan pengaruh yang positif dan signifikan terhadap kinerja ASN. Artinya semakin tinggi kompensasi yang diterima ASN, maka kinerja PNS pada Kantor Kementerian Agama Kota Baubau semakin meningkat. Dengan demikian hipotesis kedua yang diajukkan dalam penelitian ini dapat diterima atau didukung oleh fakta empiris hasil penelitian.

Hasil uji hipotesis $\mathrm{H} 1$ (pengaruh budaya kerja terhadap kinerja ASN) dan $\mathrm{H} 2$ (pengaruh kompensasi terhadap kinerja ASN) disajikan pada Tabel 8.

Pengujian Secara Simultan (uji F dan R2) Hipotesis Ketiga (H3). Peneliti melakukan pengujian hipotesis pengaruh budaya kerja dan kompen sasi untuk ASN di kementerian agama di Kantor Agama Kota Baubau, dengan menggunakan istilah ASN sebagai faktor yang menggantikan variabel independen yang ditetapkan (Tabel 8). Hipotesis ke-3 $(\mathrm{H} 3)$ yang disarankan dalam analisis ini akan diuji secara bersamaan adalah:

\section{H3: Ada Pengaruh Signifikan Secara Simultan Antara Budaya Kerja dan Kompensasi Terhadap Kinerja ASN.}

Berdasarkan analisis dan pengukuran yang dilakukan dengan menggunakan software komputer Windows 19.00 SPSS, seperti yang terangkum dalam Tabel 7 dan Tabel 8 menunjukkan bahwa $F$ hitung sebesar 188,410> F tabel 1,39172 dengan harga signifikansi 0,000, karena signifikansi nilai $F$ yang terukur lebih kecil dari 0,05 , hal ini berarti Hipotesis ketiga $(\mathrm{H} 3)$ yang diuji dalam penelitian ini, yaitu "ada pengaruh signifikan secara simultan antara budaya kerja dan kompensasi terhadap kinerja PNS diterima. Selain itu, $(\mathrm{R} 2)=0.795$ dapat ditunjukkan dengan koefisien determinasi. Dengan kata lain, keragaman variabel kinerja ASN dapat dijelaskan oleh model sebesar $79,50 \%$ dan sisanya 20,50 \% dapat diinterpretasikan oleh faktor atau variabel lain yang tidak digunakan dalam model penelitian ini. Model ini menunjukkan bahwa jika nilai R2 yang menunjukkan kemampuan model untuk memprediksi nilai target dengan tepat lebih besar dari $60 \%$, maka hasil yang diperoleh akan sangat akurat.. Akhirnya, temuan ini juga akan menunjukkan bahwa koefisien dan pentingnya pengaruh variabel pekerjaan terhadap output ASN lebih besar daripada komunitas. Karena ini jelas merupakan komponen utama yang mempengaruhi kinerja mereka, artinya gaji mereka lebih signifikan daripada aspek lingkungan kerja lainnya di Kantor Kementerian Agama di Baubau.

Tabel 7. Coefficients

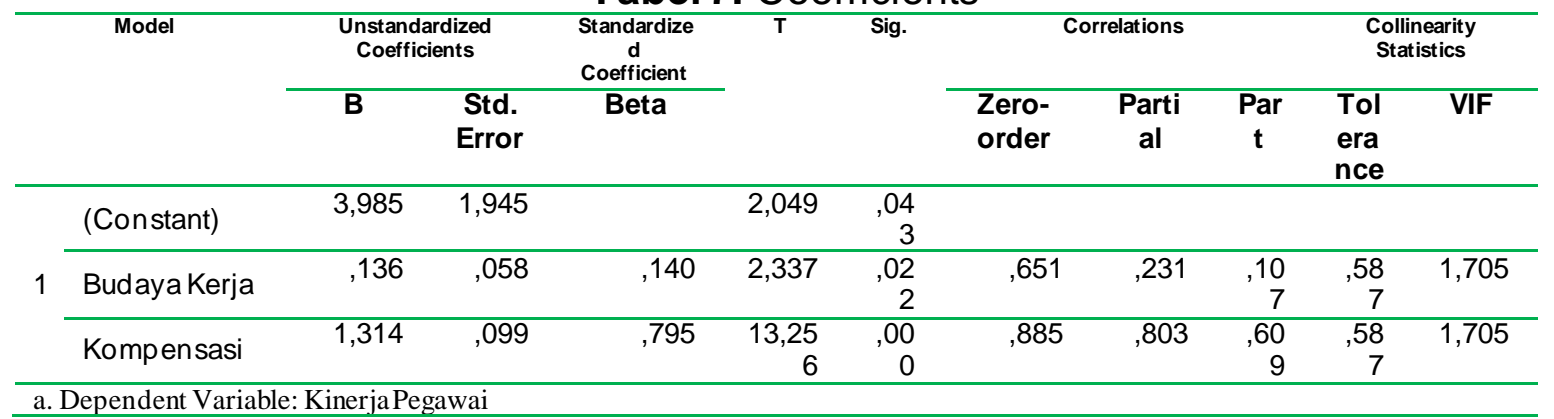


Tabel 8. Model Summary

\begin{tabular}{|c|c|c|c|c|c|c|c|c|c|}
\hline \multirow{2}{*}{$\begin{array}{l}\text { Mo } \\
\text { del }\end{array}$} & \multirow[t]{2}{*}{$\mathrm{R}$} & \multirow{2}{*}{$\begin{array}{l}\mathrm{R} \\
\text { Squ } \\
\text { are }\end{array}$} & \multirow{2}{*}{$\begin{array}{l}\text { Adjusted } \\
\text { R Square }\end{array}$} & \multirow{2}{*}{$\begin{array}{l}\text { Std. Error of } \\
\text { the Estimate }\end{array}$} & \multicolumn{5}{|c|}{ Change Statistics } \\
\hline & & & & & $\begin{array}{c}\mathrm{R} \\
\text { Square } \\
\text { Change }\end{array}$ & $\begin{array}{c}\mathrm{F} \\
\text { Change }\end{array}$ & $\mathrm{df} 1$ & $\mathrm{df} 2$ & $\begin{array}{l}\text { Sig. F } \\
\text { Change }\end{array}$ \\
\hline 1 & $\begin{array}{l}.89 \\
2^{\mathrm{a}}\end{array}$ & ,795 & ,791 & 1,495 & ,795 & $\begin{array}{c}188,41 \\
0\end{array}$ & 2 & 97 &, 000 \\
\hline
\end{tabular}

a. Predictors: (Constant), Kompensasi, Budaya Kerja

\section{Pembahasan}

\subsection{Pengaruh Budaya Kerja Terhadap Kinerja ASN Pada Kantor Kementerian Agama Kota Baubau}

Hasil uji hipotesis $(\mathrm{H} 1)$ telah membuktikan bahwa berpengaruh secara signifikan dan positif antara budaya kerja terhadap kinerja pegawai. Berdasarkan hasil analisis disimpulkan bahwa pengaruh budaya kerja pada Kantor Kementerian Agama Baubau terhadap kinerja dengan tingkat signifikansi 95\% dan pengaruh yang cukup besar, ditetapkan bahwa budaya kerja memberikan kontribusi terhadap kinerja pada Kementerian Agama Baubau dengan koefisien kepercayaan 0,022 (kurang dari 0,05). Hasil penelitian ini sesuai dengan pen elitian lqbal (lqbal, 2017) yang menganalisis pengaruh budaya kerja terhadap kinerja, dimana hasil penelitian menunjukkan bahwa budaya kerja sebagian berpengaruh positif terhadap hasil kerja karyawan. Ini sesuai dengan nilai r 0,740. Artinya dampaknya tinggi, sedangkan besarnya faktor determinasi 0,547 mengartikan bahwa variabel budaya kerja memberikan kontribusi terhadap keberhasilan karyawan sebesar 45,3 persen, sedangkan sisanya sebesar 28,8 persen.

Temuan penelitian tentang variabel kerja sangat mempengaruhi kinerja sejalan dengan hasil penelitian (Pradana, 2012) bahwa budaya kerja menunjang kegiatan pegawai/karyawan. Sejalan pula dengan penelitian (Paschal, Anozie Obinna Nizam, 2016) bahwa budaya seperti (berdoa, nilai dan norma, dan ketulusan) seseorang memiliki pengaruh yang besar dan signifikan terhadap kinerja karyawan. Aktivitas budaya yang sering dilakukan itu sangat bagus dan dampak positif pada kinerja karyawan. Sementara itu (Safrizal, 2014) menunjukkan bahwa suasana kerja merupakan elemen penting dalam keberhasilan karyawan. Budaya kerja yang sehat pasti dapat dikaitkan dengan peningkatan kinerja karyawan secara individu.

Hubungan indikator disiplin terhadap kinerja ASN sangat erat dalam hal ini menunjukkan bahwa disiplin yang dilakukan ASN dapat meningkatkan prestasi kerja yang menghasilkan kualitas yang baik, sesuai target (kuantitas) dan tepat waktu. Hubungan indikator keterbukaan terhadap kinerja ASN sangat erat dalam hal ini menunjukkan bahwa keterbukaan yang dilakukan ASN dapat meningkatkan prestasi kerja yang menghasilkan kualitas yang baik, sesuai target (kuantitas) dan tepat waktu. Hasil analisis mendeskripsikan hubungan saling menghargai sudah menjadi budaya kerja ASN sehingga mampu meningkatkan yang menghasilkan kualitas yang baik, sesuai target (kuantitas) dan tepat waktu. Terhadap indikator kerjasama berjalan dengan sangat baik dan menjadi faktor penting dalam bekerja (budaya). Artinya, hubungan antara kerjasama dengan budaya kerja ASN mampu 
meningkatkan kinerja ASN yang menghasilkan kualitas yang baik, sesuai target (kuantitas) dan tepat waktu .

\subsection{Pengaruh Kompensasi Terhadap Kinerja ASN Pada Kantor Kementerian Agama Kota Baubau}

Hasil pengujian hipotesis $(\mathrm{H} 2)$ telah membuktikan bahwa terdapat pengaruh signifikan dan positif antara kompensasi terhadap kinerja pegawai. Berdasarkan hasil analisis diperoleh pengaruh kompensasi terhadap kinerja ASN Kantor Kementerian Agama Kota Baubau dengan nilai signifikansi 0,000 (kurang dari $0,05)$, dengan tingkat kepercayaan $95 \%$ dapat dinyatakan terdapat pengaru $\mathrm{h}$ yang signifikan dan positif kompensasi terhadap kinerja pegawai. Hasil penelitian ini

membuktikan pada beberapa kajian sebelumnya bahwa kinerja sangat berpengaruh terhadap kompensasi atau gaji atau honor, ataupun sebaliknya bahwa kompensasi memiliki dampak terhadap kinerja. Sebagaimana hasil penelitian (Sugiyarti, 2008) dalam menganalisis hubungan keduanya dimana kompensasi berdampak positif dan penting terhadap produktivitas karyawan. Semakin tinggi bayarannya, semakin baik kepuasan karyawan. Hasil penelitian ini sejalan dengan penelitian (Rohmah, 2013) bahwa kompensasi berpengaruh signifikan terhadap kinerja, yang menunjukkan bahwa semakin banyak sekolah memberikan kompensasi untuk itu, semakin baik hasilnya. Selanjutnya faktor dominan berpengaruh terhadap kinerja salah satunya adalah kompensasi. Begitupun penelitian yang dilakukan oleh (Khusna, 2015) dimana kompensasi meningkatkan kinerja secara signifikan, yang berarti kompensasi merupakan sumber motivasi karyawan, yang mengarah pada kinerja yang lebih baik dan merupakan bukti bahwa kompensasi berkontribusi padanya.

Tanggapan responden mengenai variabel kompensasi pada indikator kompensasi finansial langsung terhadap kinerja ASN menunjukkan tanggapan responden dengan kategori sangat baik. Hubungan indikator kompensasi finansial langsung terhadap kinerja ASN sangat erat dalam hal ini menunjukkan bahwa kompensasi finansial langsung yang diberikan kepada PNS dapat meningkatkan kinerja ASN yang menghasilkan kualitas yang baik, sesuai target (kuantitas) dan tepat waktu. Hubungan indikator kompensasi finansial tidak langsung terhadap kinerja ASN sangat erat dalam hal ini menunjukkan bahwa kompensasi finansial tidak langsung yang diberikan kepada ASN dapat meningkatkan kinerja ASN yang menghasilkan kualitas yang baik, sesuai target (kuantitas) dan tepat waktu. Selanjutnya, hubungan indikator kompensasi non finansial terhadap kinerja ASN sangat erat dalam hal ini menunjukkan bahwa kompensasi non finansial yang diberikan kepada ASN dapat meningkatkan kinerja ASN yang menghasilkan kualitas yang baik, sesuai target (kuantitas) dan tepat waktu.

\subsection{Pengaruh Budaya Kerja dan Kompensasi Terhadap Kinerja ASN Pada Kantor Kementerian Agama Kota Baubau}

Melalui temuan hipotesis $(\mathrm{H} 3)$ dalam penelitian ini, korelasi kuat telah ditemukan antara kepuasan kerja dan kesuksesan sangat besar dan terbukti signifikan dan positif. Berdasarkan hasil analisis diperoleh pengaruh budaya kerja dan kompensasi terhadap kinerja ASN Kantor Departemen Agama Kota Baubau dengan nilai signifikansi 0,000 (kurang dari 0,05), dengan tingkat kepercayaan 95 $\%$ dapat dinyatakan bahwa ada pengaruh yang signifikan secara simultan antara budaya kerja dan kompensasi terhadap kinerja ASN. 
Tanggapan responden mengenai variabel budaya kerja dan kompensasi kinerja pada indikator kualitas kerja dalam kategori sangat baik. Dengan demikian, maka hubungan budaya kerja dan kompensasi terhadap indikator kualitas kerja ASN Kantor Departemen Agama Kota Baubau sangat erat. Oleh karena itu, dapat ditarik kesimpulan dimana budaya kerja oleh ASN dan kompensasi yang diberikan kepada ASN dapat meningkatkan kualitas kerja dan secara bersamaan kinerja ASN juga akan baik.

Hubungan budaya kerja dan kompensasi terhadap indikator kuantitas kerja ASN sangat erat. Oleh karena itu, dapat ditarik kesimpulan bahwa budaya kerja oleh ASN dan kompensasi yang diberikan kepada ASN dapat meningkatkan kuantitas kerja yang secara bersamaan kinerja ASN juga akan baik. Hubungan budaya kerja dan kompensasi terhadap indikator ketepatan waktu kerja ASN Kantor Kementerian Agama Kota Baubau sangat erat. Oleh karena itu, dapat ditarik kesimpulan bahwa budaya kerja oleh ASN dan kompensasi yang diberikan kepada ASN dapat meningkatkan ketepatan waktu kerja yang secara bersamaan kinerja ASN juga akan baik.

Studi hubungan budaya kinerja dan kompensasi terhadap kinerja PNS mengisyaratkan suatu bahwa suatu fungsi lembaga akan sangat bergantung pada kinerja pegawai/karyawan. Kinerja dibutuhkan kemampuan skill, tidak hanya itu juga memiliki budaya atau etos kerja sehingga mampu mencapai visi serta misi organisasi. Budaya organisasi memiliki pengaruh yang cukup besar terhadap kinerja karena mengatur bagaimana tugas dilaksanakan, prosedur kerja, kondisi kerja, efisiensi kerja dinilai, dan stabilitas organisasi (Wanjiku, Njungi Anne Agusioma, n.d.).

Pada penelitian ini, kinerja pegawai sangat ditentukan oleh kuantitas dan kualitas kerja serta tepat waktu yang sangat berpengaruh terhadap budaya kerja dan kompensasi. Sejalan dengan itu, Wanjiku (Wanjiku, Njungi Anne Agusioma, n.d.) dalam penelitiannya di World Vision, Kenya dimana integrasi budaya pegawai/karyawan mulai dari budaya kompetitif (kualitas dan kuantitas terukur), budaya kemandirian (mampu menyelesaikan tugas secara mandiri/berkelompok dan tepat waktu), serta budaya kerja membawa fakta bahwa karyawan mencari lingkungan kerja yang dapat memaksimalkan kemampuan mereka (kompensasi) agar menjadi pribadi yang lebih inovatif, kreatif, serta independen.

\section{Kesimpulan}

Budaya kerja berpengaruh signifikan dan positif bagi kinerja ASN di Kantor Kementerian Agama Kota Baubau. Disiplin, keterbukaan, saling menghargai dan kerjasama adalah cerminan budaya kerja PNS dan dianggap mampu meningkatkan kinerja PNS. Di Kantor Kementerian Agama Kota Baubau, kompensasi memiliki dampak penting dan konstruktif dalam menyukseskan kerja ASN. Kompensasi yang diberikan kepada karyawan meliputi kompensasi finansial langsung, kompensasi non finansial dan finansial tidak langsung.

Budaya kerja dan kompensasi berpengaruh langsung dan positif terhadap kinerja ASN di Kantor Kementerian Agama Kota Baubau. Kinerja pegawai yang berpengaruh terhadap budaya kerja dan kompensasi meliputi kualitas dan kuantitas kerja serta ketepatan waktu.

\section{Daftar Pustaka}


Bangun, W. (2012). Manajemen Sumber Daya Manusia. Erlangga Group.

Frinaldi, A. (2014). Pengaruh Budaya Kerja Pegawai Negeri Sipil Terhadap Pelayanan Publik Di Dinas Catatan Sipil dan Kependudukan Kota Payakumbuh. Jurnal Humanis, 8(2).

Ghozali, I. (2005). Aplikasi Analisis Multivariate dengan Program SPSS. Penerbit BP Universitas Diponegoro.

Golung, H. D. (2013). Relationship Between Compensation, Work Environment, Organizational Culture, And Employee Performance At Hotel Sedona Manado. Jurnal EMBA, 1.

Hasibuan, M. S. (2008). Manajemen Sumber Daya Manusia. Penerbit Bumi Aksara.

lqbal, M. (2017). Pengaruh Budaya Kerja dan Pengawasan Terhadap Kinerja Karyawan (Studi Kasus di PT Bank DKI Capem Syariah Margonda, Depok). Jurnal Transparansi Ilmiah IImu Administrasi., 9(2).

Khusna, N. (2015). Pengaruh Kompensasi dan Lingkungan Kerja Terhadap Kinerja Serta Kinerja Karyawan Pada Sub Sector Industry Pengolahan Kayu Skala Menengah di Jakarta Timur. niversitas Khatolik Widya Mandala, Surabaya.

Lidya, M., \& Hati, S. W. (2015). Pengaruh Kualitas Pelayanan Akademik Terhadap Kepuasan Mahasiswa Di Politeknik Negeri Batam. Jurnal Akuntansi, Ekonomi Dan Manajemen Bisnis, 3(1), 1-9.

Paschal, Anozie Obinna Nizam, I. (2016). Effects of Organisational Culture on Employees Performance: Case of Singapore Telecommunication. Journal of Accounting \& Business Management., 4(1).

Pradana, R. G. R. (2012). Pengaruh Budaya Kerja Terhadap Kinerja Karyawan Di Koperasi Karyawan Redryng Bojonegoro. (Tesis). Jurusan Sosial Ekonomi Pertanian Fakultas Pertanian Universitas Brawijaa, Malang.

Rivai, V., \& Sagala, E. J. (2009). Manajemen Sumber Daya Manusia untuk Perusahaan. PT. Raja Grafindo Persada.

Rohmah, S. (2013). Pengaruh Kompetensi. Kompensasi, Disiplin Kerja Terhadap Kinerja dan Kepuasaan Kerja Guru SMA Islimic Village Karawaci Tangerang. Program Pascasarjana Universitas Esa Tunggal, Jakarta.

Safrizal, S. M. S. C. (2014). Pengaruh Budaya Kerja, Kemampuan dan Komitmen Pegawai Terhadap Kinerja Pegawai serta Dampaknya Pada Kinerja Dinas Pertambangan dan Energi Aceh. Jurnal Manajemen., 3(2), 44-53.

Shalahuddin, A. (2014). Pengaruh Kompensasi Dan Budaya Organisasi Terh adap Kinerja Pegawai Dengan Motivasi Kejra Sebagai Variabel Perantara. Jurnal Manajamen Teori Dan Terapan, 7(1).

Soeprihanto, J. (2000). Penilaian Kinerja dan Pengembangan Karyawan. EPFE.

Sugiyarti, G. (2008). Pengaruh Lingkungan Kerja, Budaya Organisasi dan Kompensasi Terhadap kepuasan kerja Untuk Meningkatkan Kinerja Pegawai (Studi Pada Fakultas Ekonomi Universitas 17 Agustus 1945 Semarang). Semarang. Jurnal IImiah Serat Acitya. 
Suwandi, M. M. (2021). Pengaruh Kompensasi Terhadap Kinerja Karyawan yang di Mediasi Kepuasan Kerja pada PT ISS Cikarang. Jurnal Ekonomi \& Ekonomi Syariah, 4(1).

Wanjiku, Njungi Anne Agusioma, N. L. (n.d.). Effect of Organisation Culture on Employee Performance in Non Govermental Organizations. International Journal of Scientific and Research Publications, 4(11).

Zulkifli, M., \& Dkk. (2014). Motivasi Kerja, Sertifikasi, Kesejahteraan dan Kinerja Guru. Persona, Jurnal Psikologi Indonesia, 3(2). 